\title{
The Effect of Microstructure on Mechanical Properties of Phyllostachys pubescens
}

\author{
Xin Guan, ${ }^{*}$ Haining Yin, Bowen Chen, Yan Zhu, Xueshen Liu, and Jinguo Lin* \\ To reveal the effects of vascular bundle and sheath-node tissues on \\ mechanical strength, moso bamboo (Phyllostachys pubescens) was \\ investigated via compression, bending, and tension tests. Quantitative \\ analysis was applied on vascular bundle and sheath-node tissues using \\ a mosaicking technique and Image-Pro Plus 6.0 software. Based on the \\ analysis of internode and node specimens, it was found that 1) there was \\ a significant difference between the tissues proportion and mechanical \\ strength. A high tissues proportion resulted in a high compression \\ strength, tension strength, and modulus of rupture, but a low modulus of \\ elasticity. 2) There was no significant correlation between the tissues \\ proportion and failure modes. 3) The presence of a bamboo node \\ decreased the modulus of rupture, modulus of elasticity, and tension \\ strength, but it did not affect the compression strength. 4) A bamboo \\ node increased the likelihood of brash tension failure in the bending test \\ and splintering tension failure in the tension test, but decreased the \\ probability of splitting failure in the compression test. 5) The effects of \\ bamboo node on strength were due to the irregular sheath-node and \\ undifferentiated vascular bundles.
}

Keywords: Moso bamboo; Vascular bundle; Sheath-node; Mechanical property

Contact information: College of Material Engineering, Fujian Agriculture and Forestry University, Fuzhou 350002, China; *Corresponding authors: guanxin1001@sina.com; fjlinjg@126.com

\section{INTRODUCTION}

The importance and irreplaceability of bamboo resources have been recognized by an increasing number of countries around the world. Facing the sharp decline of global forest area, bamboo forest area had an average annual growth rate of $3 \%$ until 2006 (Lobovikov et al. 2007). There are as many as 1,642 bamboo species worldwide distributed in the tropic and subtropical regions, even in the temperate and frigid zones. The three largest bamboo producing areas are South America, Africa, and Asia Pacific (FAO 2010; Mao et al. 2017).

Unlike any other plants, each segment in bamboo has a meristem. Therefore, bamboo grows quickly, and moso bamboo (Phyllostachys edulis) grows the fastest (Fujii et al. 1996; Gamuyao et al. 2017). As a possible replacement material, bamboo has some important differences compared to wood. There is no radial transfer tissue (i.e., rays, radial intercellular canal, etc.) in bamboo, which leads to the low shear strength (Xu 2010). However, the vascular bundle is "plum blossom"-shaped with regular arrangement (Fig. 1), and it gives high tensile strength to bamboo, approximately 2.5 times higher than Chinese fir (Richard and Harries 2015; Jiang et al. 2017). Of course, bamboo is an organism with certain variability in its microstructure. In the radial direction, the size, numbers, and formations of vascular bundles are gradual (Fig. 1) and closely related to strength. Another characteristic is the node and internode. The former is solid with low 
density and irregular vascular bundle arrangement, while the latter is hollow (Taylor et al. 2015). As a result, the dimensions of a bamboo strip are limited by the culm-wall thickness. Today, two common bamboo elements used in bamboo-based composites are tangential and radial bamboo strip (Anwar et al. 2005; Du et al. 2013; Guan et al. 2018). In order to diminish the affect on the bonding force by the epidermal layer (bamboo outer skin) and waxy layer (bamboo inner skin), the thickness of the radial bamboo strip is thin, usually no more than $2 \mathrm{~mm}$. The radial strip would be further processed into bamboo curtain, which can only be used as a sandwich layer of bamboo curtain plywood, laminated bamboo composite lumber, etc., due to the surface irregularities. The irregular shape is due to the relatively large taper near the top of bamboo culm, because the cutter is not able to remove the bamboo node thoroughly. As a result, there are humps on both sides of the radial strip at bamboo nodes along the growth direction. In contrast, the tangential bamboo strip without bamboo outer and inner skin, and its thickness is usually $6 \mathrm{~mm}$. Thus, it can be processed into laminated bamboo lumber oriented in the edgewise and/or flatwise direction (Jiang et al. 2002). As it grows in size, the effect of heterogeneous microstructure on strength is becoming more visible. A qualitative analysis was obtained, namely a positive relationship between the strength and tissue proportion of the vascular bundle (Lo et al. 2008; Dixon and Gibson 2014; Penellum et al. 2018). However, the authors' previous study found that the sclerenchyma cells lay among vascular tissues in an irregular shape in the bamboo node, and the pattern of vascular bundle had altered (Fig. 1).

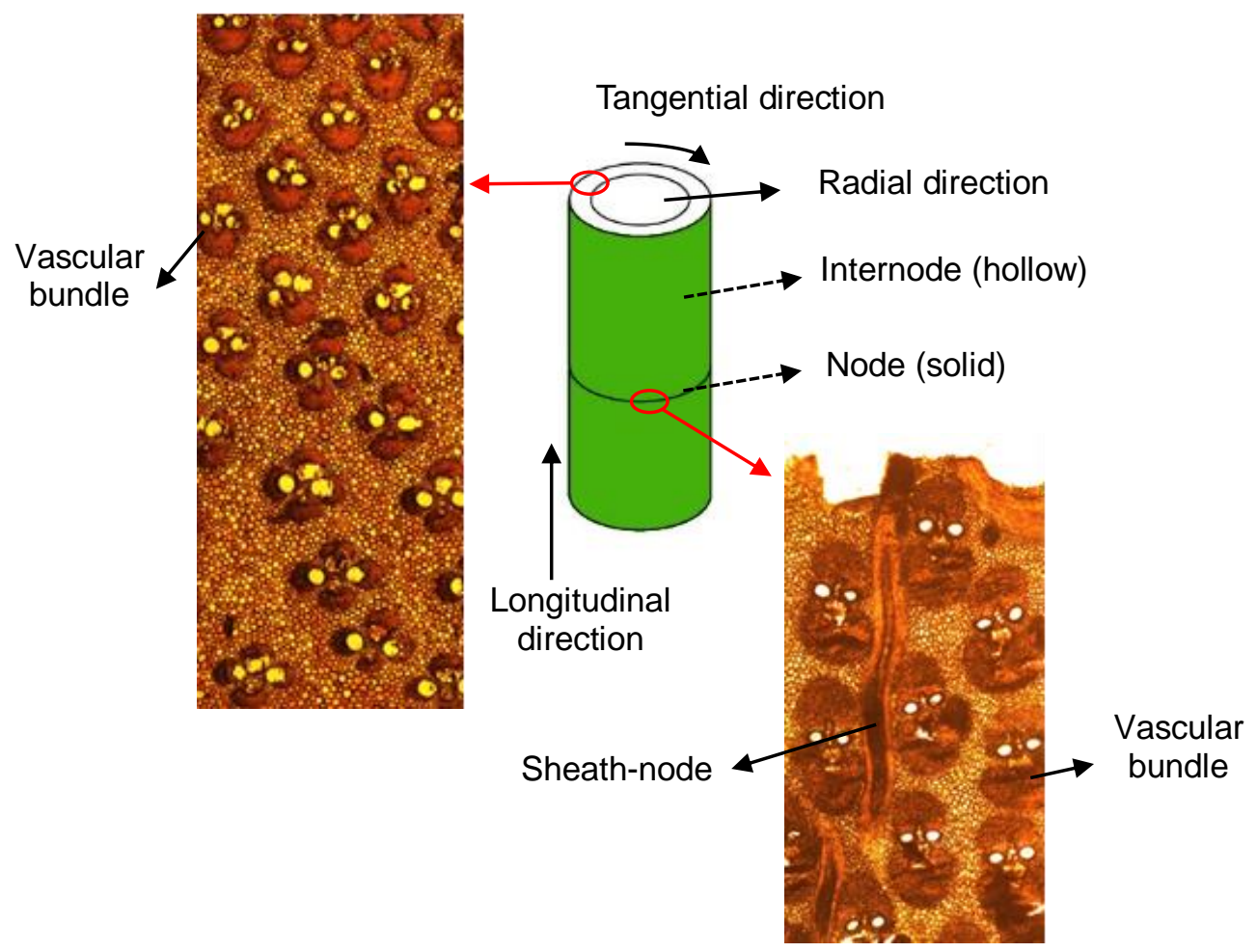

Fig. 1. Bamboo structure

The changes of microstructure are due to the growth and falling of bamboo leaves, similar to a live knot of wood. Then, this kind of tissue is called a sheath-node. In 
terms of the authors' previous study, there is an increasing proportion of sclerenchyma cells in the bamboo node. It is of interest to find out whether the bamboo node has an enhancement effect on strength. The purpose of this study was to determine the relationship between strength and microstructure in the bamboo node. Moreover, the correlation of types of failure modes and microstructure was investigated quantitatively.

\section{EXPERIMENTAL}

\section{Materials}

Specimen preparation

The moso bamboo used in the tests was 4 to 5 years old and from Sanming, Fujian Province, China. The diameter at breast height was $10 \mathrm{~cm}$. The specimens were collected from the bamboo culm at a height between $1.5 \mathrm{~m}$ and $6.0 \mathrm{~m}$. After air-drying, the specimens were cut parallel to the grain into tangential bamboo strips. The moisture content of the strips was approximately $10 \%$ during the experiment.

\section{Testing properties}

The physical and mechanical properties of specimens were tested based on GB/T 15780 (1995) Chinese national standard. The properties tested included moisture content, strength, and elasticity. The testing methods used, properties tested, number of replicates, and loading direction are given in Table 1.

Table 1. Methods for Testing Properties

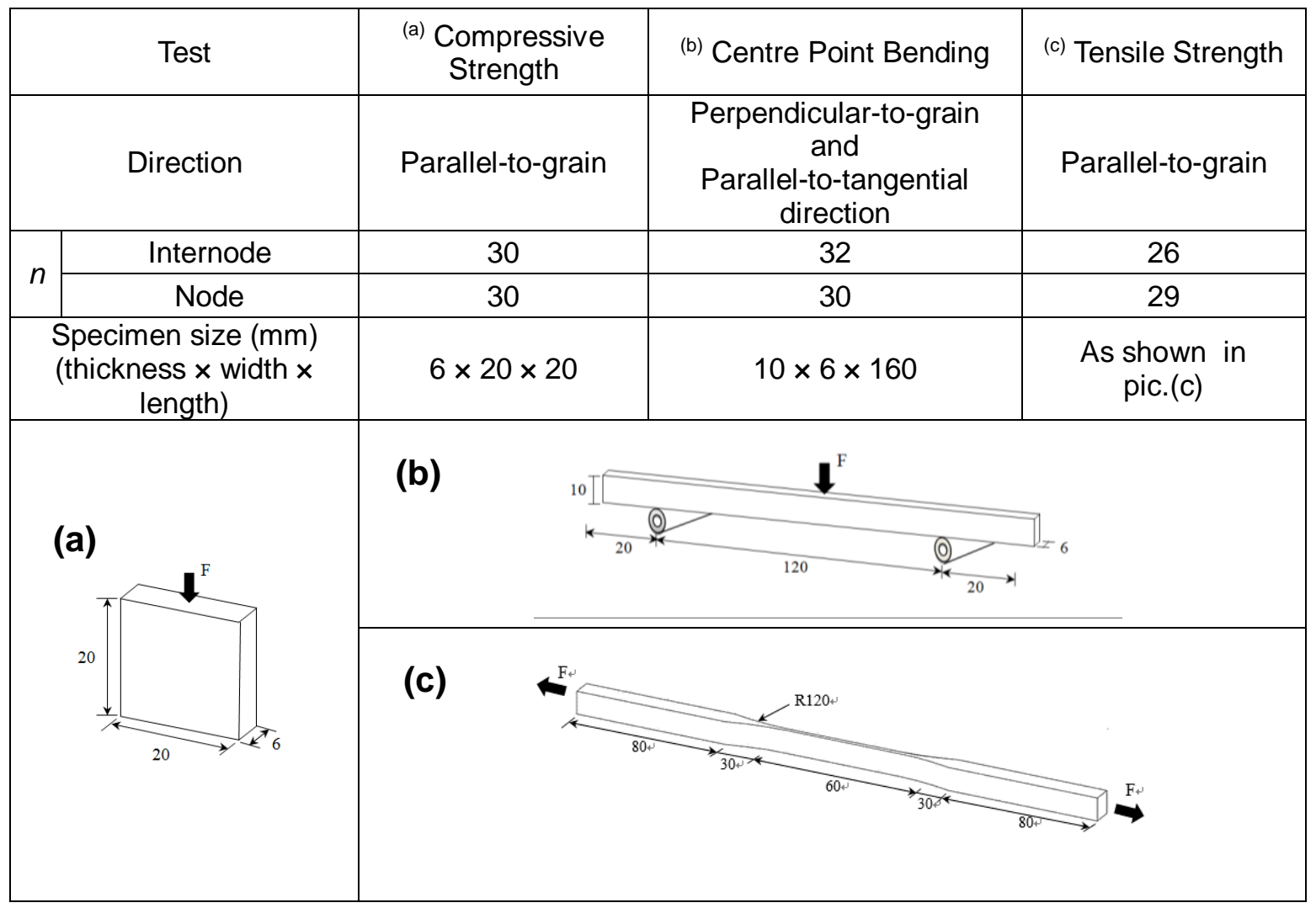


All specimens were divided into two groups. One group was made from the internode, the other was made with one node located at the centers. For the compressive strength tests, the load should be applied through a metal bearing plate of $50 \mathrm{~mm}$ in width parallel to the growth direction of the bamboo. The span for centre point bending test should be $120 \mathrm{~mm}$, measured to an accuracy of $\pm 1 \mathrm{~mm}$. Both rounded supports and loading block were used, the diameter of the round portion should be $20 \pm 0.5 \mathrm{~mm}$. The load was applied through the bearing block to the tangential surface of specimen at the centre of span. The size of end-grain surface for tensile strength tests was $10 \times 6 \mathrm{~mm}$, but $10 \times 2 \mathrm{~mm}$ at the narrow section. Other sizes of specimens were in accordance with Table 1(c). The specimen was fastened in grips, and then the load was applied continuously throughout the test. For each test piece, a moisture section approximately $20 \mathrm{~mm}$ in length was cut from the reduced section near the failure.

\section{Methods}

Determination of the tissues proportion

The image recognition method was used for quantitative measurement of the tissue proportion. Each specimen approximately $10 \mathrm{~mm}$ in length was cut from the reduced section of the mechanical test sample near by the fractured part. After $6 \mathrm{~h}$ of boiling in deionized water, all specimens were immersed in water with a temperature of approximately $80{ }^{\circ} \mathrm{C}$ for 10 days. Water would enter in the hemicellulose, lignin, and amorphous region of cellulose, which could increase the plasticity of bamboo. This softened the specimens and then they were cut into 20 - $\mu \mathrm{m}$ slices using a table microtome (REM-710; Yamato Kohki Industrial Co., Ltd., Saitama, Japan) for microscopic observation. All the slices were stained with safranine dye for $30 \mathrm{~min}$, and then dehydrated step-by-step according to Wang et al. (2018).

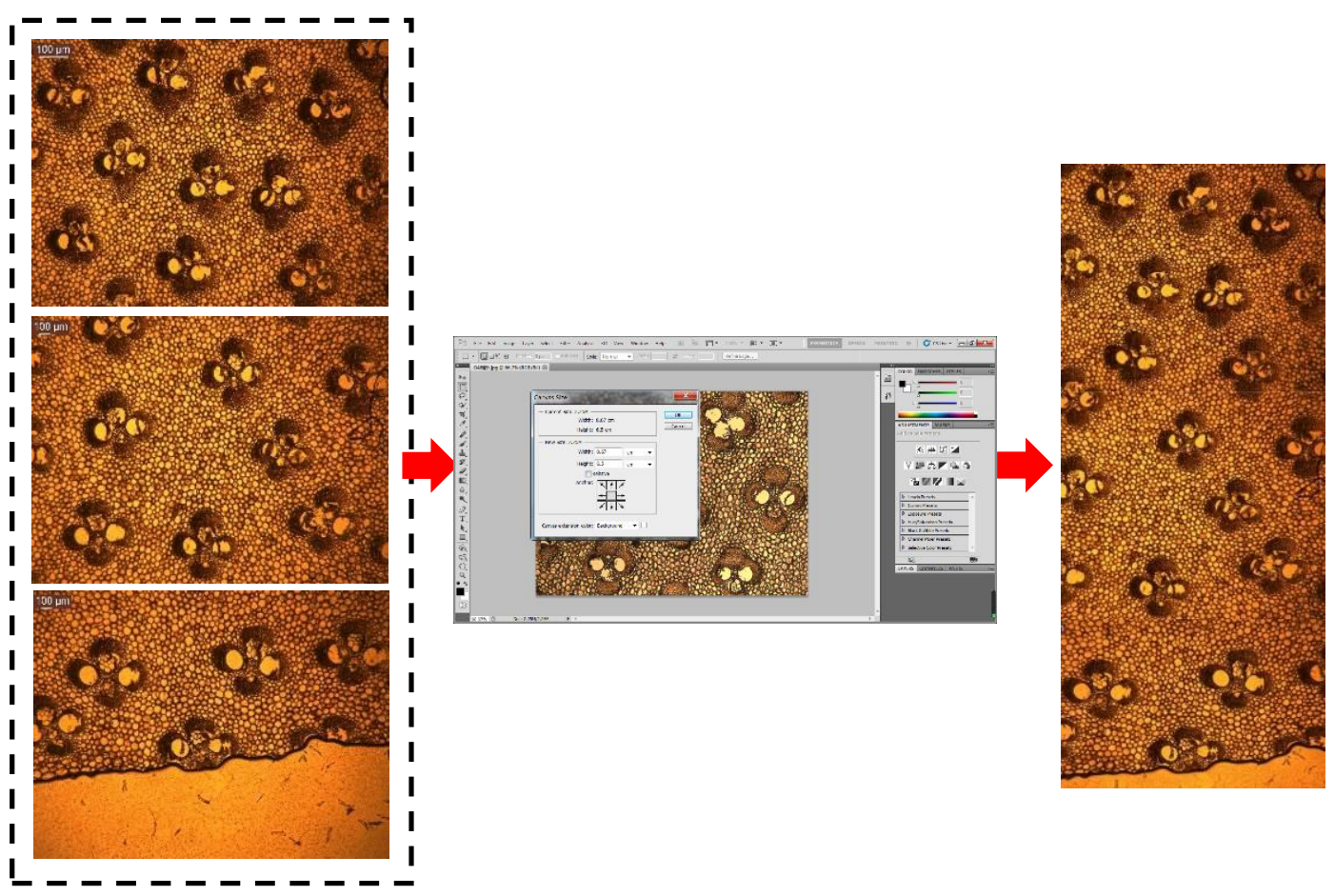

Fig. 2. Mosaic image of each slice with Photoshop 
After the above steps, slices were observed under the microscope (DM2500; Leica Microsystems Inc., Germany) with a magnification of $40 \times$. However, the microscope has a limited field of view, and this makes it impossible to see the whole microstructure of slice. To solve this problem, the image mosaicking technique provided a better view. The microscopic images were obtained from top to bottom for each slice, and then integrated into a whole one with Photoshop (Adobe Systems Incorporated, CS5, San Jose, America), as shown in Fig. 2. Afterwards, quantitative analysis on the vascular bundle and sheath-node tissues was investigated using the Image-Pro Plus 6.0 (Media Cybernetics Inc., Version 6.0, Maryland, America) software. In other words, the ratio of pixels in tissues was calculated.

\section{RESULTS AND DISCUSSION}

\section{Compressive Strength}

There were one and two outliers (based on standard deviation) in the samples for the internode group and node group, respectively. Excluding the outliers' data, the average, maximum, minimum, standard deviation, and significance data are presented in Table 2. The bamboo node had no significant impact on the compressive strength (Deng et al. 2016).

Table 2. Data Analysis of Compressive Strength between Internode and Node Specimens

\begin{tabular}{|c|c|c|c|c|c|c|c|}
\hline \multirow{3}{*}{ Summary } & Group & $\mathrm{n}$ & \multicolumn{2}{|c|}{ Mean (MPa) } & $\begin{array}{l}\text { Max. } \\
(\mathrm{MPa})\end{array}$ & $\begin{array}{l}\text { Min. } \\
(\mathrm{MPa})\end{array}$ & SD \\
\hline & Internode & 29 & \multicolumn{2}{|c|}{47.51} & 60.96 & 35.33 & 7.66 \\
\hline & Node & 28 & \multicolumn{2}{|c|}{48.34} & 61.08 & 36.26 & 6.77 \\
\hline \multirow{4}{*}{$\begin{array}{l}\text { Variance } \\
\text { Analysis }\end{array}$} & $\begin{array}{c}\text { Sources of } \\
\text { variation }\end{array}$ & SS & $d f$ & MS & $\mathrm{F}$ & P-value & Significance \\
\hline & Between & 9.73163 & 1 & 9.73163 & 0.18575 & 0.66816 & $\begin{array}{c}\text { Not } \\
\text { significant }\end{array}$ \\
\hline & Within & 2881.43 & 55 & 52.3896 & & & \\
\hline & Sum & 2891.16 & 56 & & & & \\
\hline
\end{tabular}

SS: stdev square; df: degree of freedom; MS: mean square; SD: standard deviation

The relationship of compressive strength and proportion of vascular bundle for internode and node specimens are given in Fig. 3 and Table 3. There were three and four invalid samples for internode and node specimens, respectively. It was found that the compressive strength was significantly and positively related to the proportion of vascular bundle (Zhang et al. 2017a). The internode specimens could produce models with better $\mathrm{R}^{2}$. For the node specimens, the irregular tissue arrangement led to additional uncertainty. The proportion of vascular bundle distributed in the internode was among $26 \%$ to $38 \%$, which was a little higher than that in the bamboo node. 


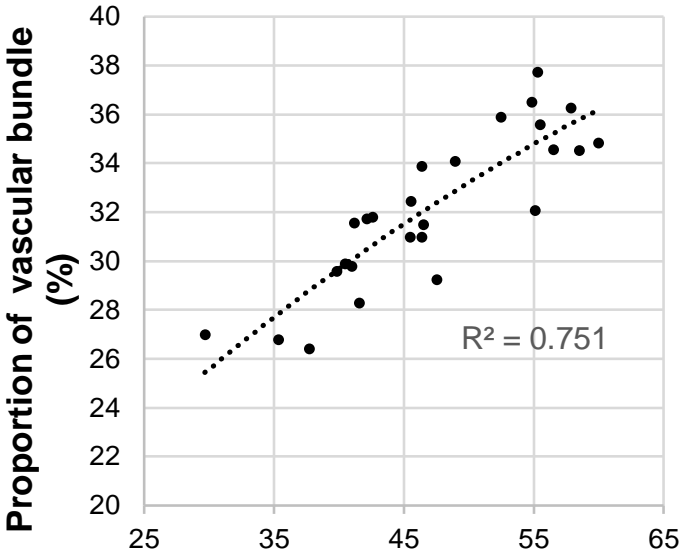

(a) Compressive strength (MPa)

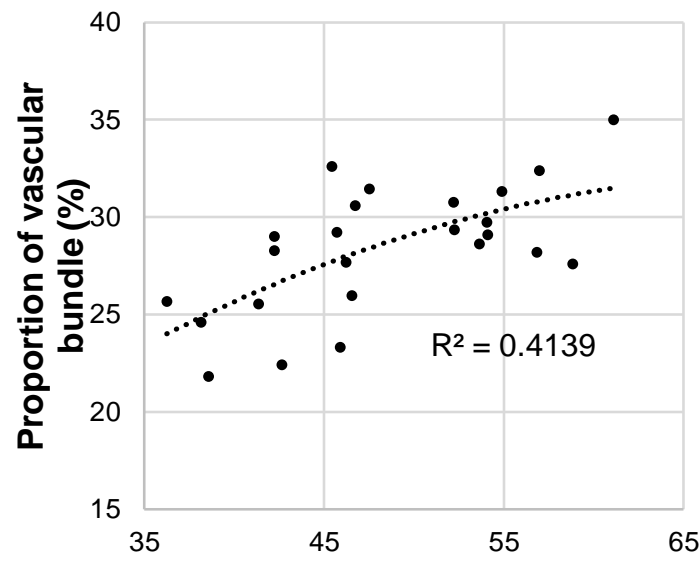

(b) Compressive strength (MPa)

Fig. 3. Relationship between compressive strength and proportion of vascular bundle: (a) internode and (b) node

Table 3. Variance Analysis on Compressive Strength and Proportion of Vascular Bundle

\begin{tabular}{|c|c|c|c|c|c|c|c|}
\hline \multicolumn{2}{|c|}{ Sources of Variation } & SS & df & MS & F & P-Value & Significance \\
\hline \multirow{3}{*}{ Internode } & Between & 2925.44 & 1 & 2925.44 & 80.0884 & $5.9 \mathrm{E}-12$ & Significant \\
\cline { 2 - 8 } & Within & 1826.38 & 50 & 36.5276 & & & \\
\cline { 2 - 8 } & Sum & 4751.82 & 51 & & & & \\
\hline \multirow{3}{*}{ Node } & Between & 4788.39 & 1 & 4788.39 & 160.673 & $1.3 \mathrm{E}-16$ & Significant \\
\cline { 2 - 8 } & Within & 1370.9 & 46 & 29.8021 & & & \\
\cline { 2 - 8 } & Sum & 6159.29 & 47 & & & & \\
\hline
\end{tabular}

SS: stdev square; df: degree of freedom; MS: mean square

During testing, there were two types of failure modes observed in all tested specimens. One was splitting, and the other was brooming (Fig. 4) (Mackenzie-Helnwein et al. 2003).

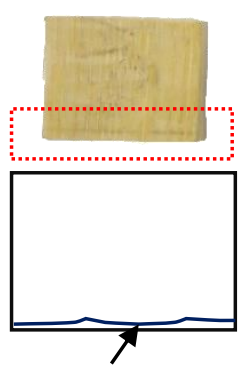

Failure mode

(a)
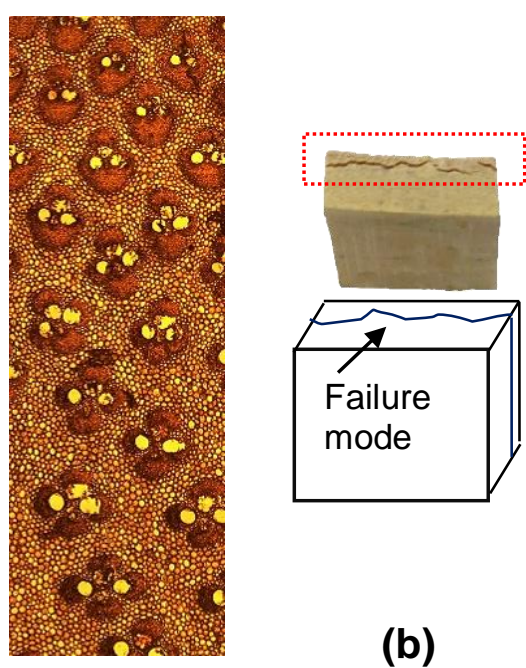

(b)

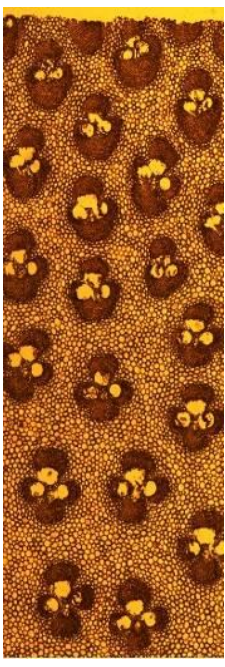

Fig. 4. Brooming (a) and splitting (b) 
Approximately $54.2 \%$ pieces failed in the form of brooming for the internode specimens, but $75 \%$ for the node specimens. This was probably because of the sheathnode that contributed to transverse binding. Further research indicated that there was no significant correlation between the failure modes and proportion of tissue in terms of variance analysis. Therefore, failure mode relates to the tissue distribution. In addition to the sheath-node, the vascular bundles gradually decreased from the outer skin to the inner skin. If the gradient distribution was obvious, it was revealed that the splitting mode resulted from the longitudinal sliding displacement of the parenchyma, and the failure occurred near the inner skin.

\section{Centre Point Bending}

Each group had an outlier, whether they were internode or node specimens. The data analysis, except for the outliers, is shown in Tables 4 and 5. It was revealed that modulus of rupture (MOR) and modulus of elasticity (MOE) of internode specimens increased $16.92 \%$ and $10.24 \%$, respectively, compared with the node specimens. Moreover, the bamboo node had significant influence on the MOR and MOE values (Ribeiro et al. 2017).

Table 4. Data Analysis of MOR between Internode and Node Specimens

\begin{tabular}{|c|c|c|c|c|c|c|c|c|}
\hline \multirow{3}{*}{ Summary } & Group & $n$ & \multicolumn{2}{|c|}{ Mean (MPa) } & Max. (MPa) & \multicolumn{2}{|c|}{$\begin{array}{l}\text { Min. } \\
(\mathrm{MPa})\end{array}$} & SD \\
\hline & Internode & 31 & \multicolumn{2}{|c|}{138.31} & 169.17 & \multicolumn{2}{|c|}{109.83} & 15.20 \\
\hline & Node & 29 & \multicolumn{2}{|c|}{118.29} & 135.14 & 102 & & 8.70 \\
\hline \multirow{4}{*}{$\begin{array}{l}\text { Variance } \\
\text { Analysis }\end{array}$} & $\begin{array}{c}\text { Sources } \\
\text { of } \\
\text { Variation }\end{array}$ & SS & df & MS & $\mathrm{F}$ & $\begin{array}{c}\mathrm{P}- \\
\text { value }\end{array}$ & \multicolumn{2}{|c|}{ Significance } \\
\hline & Between & 6003.997 & 1 & 6003.997 & 38.48821 & $\begin{array}{c}6.27 \mathrm{E}- \\
08\end{array}$ & \multicolumn{2}{|c|}{ Significant } \\
\hline & Within & 9047.753 & 58 & 155.9957 & & & & \\
\hline & Sum & 15051.75 & 59 & & & & & \\
\hline
\end{tabular}

SS: stdev square; df: degree of freedom; MS: mean square; SD: standard deviation

Table 5. Data Analysis of MOE between Internode and Node Specimens

\begin{tabular}{|c|c|c|c|c|c|c|c|c|}
\hline \multirow{3}{*}{ Summary } & Group & $n$ & \multicolumn{2}{|c|}{ Mean (MPa) } & Max. (MPa) & \multicolumn{2}{|c|}{ Min. (MPa) } & SD \\
\hline & Internode & 31 & \multicolumn{2}{|c|}{10393.17} & 11943.16 & \multicolumn{2}{|c|}{8503.91} & 900.65 \\
\hline & Node & 27 & \multicolumn{2}{|c|}{9427.44} & 10437.14 & 8233. & & 481.91 \\
\hline \multirow{4}{*}{$\begin{array}{l}\text { Variance } \\
\text { Analysis }\end{array}$} & $\begin{array}{c}\text { Sources of } \\
\text { Variation }\end{array}$ & SS & df & MS & $\mathrm{F}$ & P-value & \multicolumn{2}{|c|}{ Significance } \\
\hline & Between & $1.3 E+07$ & 1 & $1.3 \mathrm{E}+07$ & 24.8091 & $6.4 \mathrm{E}-06$ & \multicolumn{2}{|c|}{ Significant } \\
\hline & Within & $3 E+07$ & 56 & \multirow[t]{2}{*}{542376} & & & \\
\hline & Sum & $4.4 \mathrm{E}+07$ & 57 & & & & & \\
\hline
\end{tabular}

SS: stdev square; df: degree of freedom; MS: mean square; SD: standard deviation

The relationship of bending strength and tissues proportion for internode and node specimens is given in Fig. 5, Table 6, and Table 7. Eleven effective slicing data were collected for each group. It was found that the bending strength of the internode group was significantly and positively related to the proportion of vascular bundle, and the MOR could produce models with better $\mathrm{R}^{2}$. When there was a bamboo node, the MOR and MOE were dispersed and decreased with increased tissues proportion. This was because of the existence of a sheath-node that was irregular, various-shaped, and 
uncertain amounts. In addition, the sheath-node undermined the ordered arrangement of the vascular bundle and interrupted the fiber length in the longitudinal direction (Peng et al. 2014; Huang et al. 2015; Zhang et al. 2017b). Compared to the internode group, the tissues proportion of the node group was higher, among $28 \%$ and $45 \%$. However, it had no contribution to bending strength. The proportion of vascular bundle located in the internode was among $25 \%$ and $31 \%$.

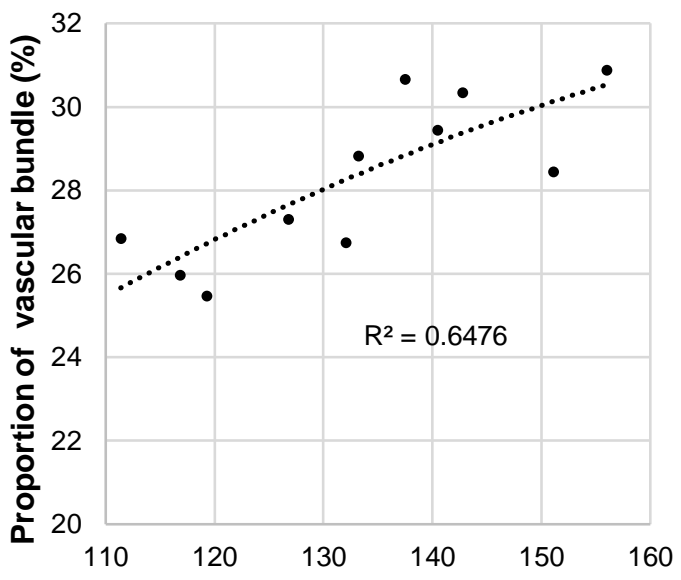

(a) MOR of internode specimens (MPa)

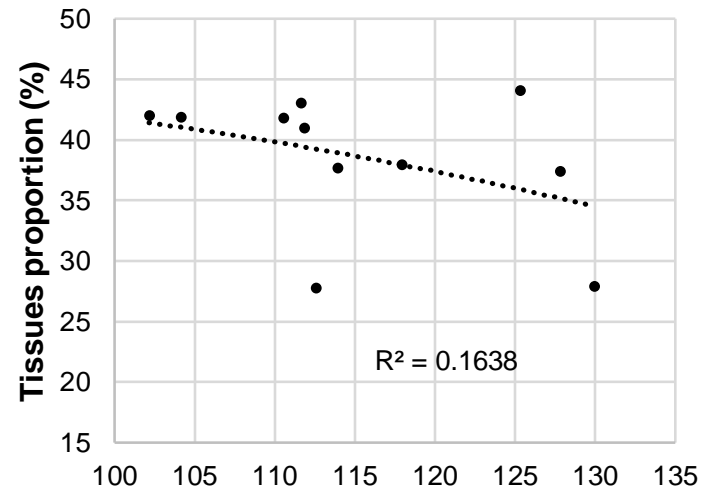

(c) MOR of node specimens (MPa)

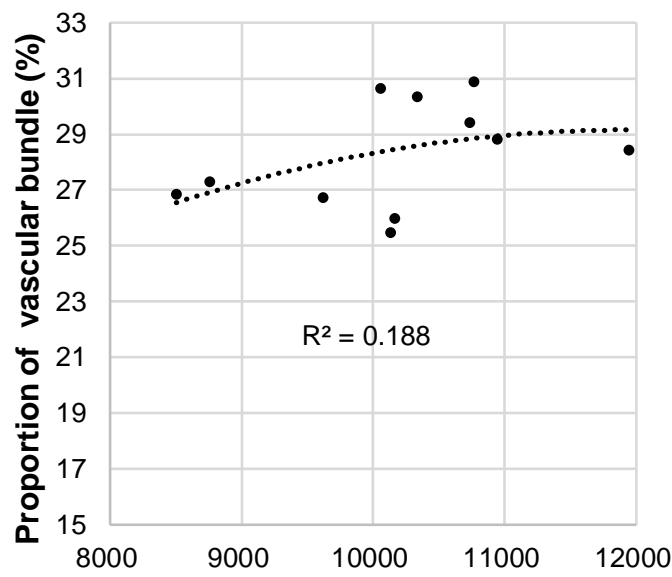

(b) MOE of internode specimens

(MPa)

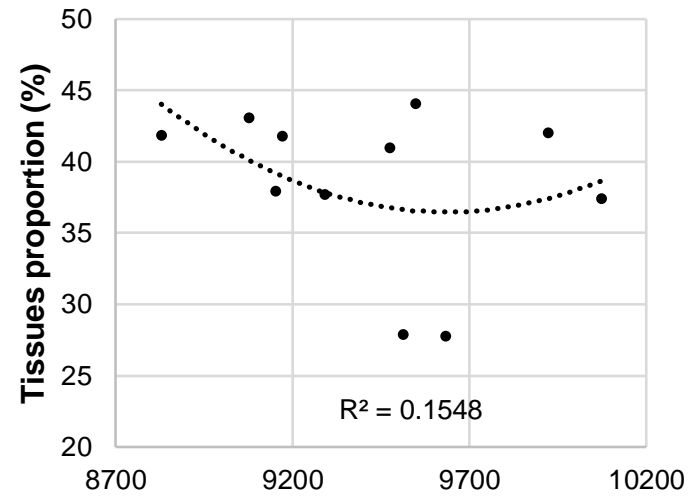

(d) MOE of node specimens (MPa)

Fig. 5. Relationship between bending strength and tissues proportion: (a) MOR of internode pieces; (b) MOE of internode pieces; (c) MOR of node pieces, and (d) MOE of node pieces

Table 6. Variance Analysis of MOR and Tissues Proportion

\begin{tabular}{|c|c|c|c|c|c|c|c|}
\hline \multicolumn{2}{|c|}{ Sources of Variation } & SS & df & MS & F & P-value & Significance \\
\hline \multirow{3}{*}{ Internode } & Between & 60735.2 & 1 & 60735.2 & 601.881 & $2.1 \mathrm{E}-16$ & Significant \\
\cline { 2 - 8 } & Within & 2018.18 & 20 & 100.909 & & & \\
\cline { 2 - 9 } & Sum & 62753.4 & 21 & & & & \\
\hline \multirow{3}{*}{ Node } & Between & 31771.14 & 1 & 31771.14 & 509.5666 & $1.06 \mathrm{E}-15$ & Significant \\
\cline { 2 - 8 } & Within & 1246.987 & 20 & 62.34935 & & & \\
\cline { 2 - 8 } & Sum & 33018.13 & 21 & & & & \\
\hline
\end{tabular}

SS: stdev square; df: degree of freedom; MS: mean square 
Table 7. Variance Analysis of MOE and Tissues Proportion

\begin{tabular}{|c|c|c|c|c|c|c|c|}
\hline \multicolumn{2}{|c|}{ Sources of Variation } & SS & df & MS & F & P-value & Significance \\
\hline \multirow{3}{*}{ Internode } & Between & $5.7 \mathrm{E}+8$ & 1 & $5.7 \mathrm{E}+8$ & 1188.75 & $2.7 \mathrm{E}-19$ & Significant \\
\cline { 2 - 8 } & Within & 9528049 & 20 & 476402 & & & \\
\cline { 2 - 8 } & Sum & $5.8 \mathrm{E}+8$ & 21 & & & & \\
\hline \multirow{3}{*}{ Node } & Between & $4.85 \mathrm{E}+8$ & 1 & $4.85 \mathrm{E}+8$ & 7086.908 & $5.5 \mathrm{E}-27$ & Significant \\
\cline { 2 - 8 } & Within & 1367341 & 20 & 68367.05 & & & \\
\cline { 2 - 8 } & Sum & $4.86 \mathrm{E}+8$ & 21 & & & & \\
\hline
\end{tabular}

SS: stdev square; df: degree of freedom; MS: mean square

All specimens started cracking at the tension side, then some of them fractured in the form of brash tension, and others in the form of simple tension (Fig. 6). There were approximately $36.4 \%$ samples that failed in the form of brash tension for internode samples, but $100 \%$ for node samples. Meanwhile, all the cracks of node samples were from the node. Furthermore, it was found that the vascular bundles were not fully differentiated (Fig. 6c), which was one of the main reasons that led to low bending strength.

(a)

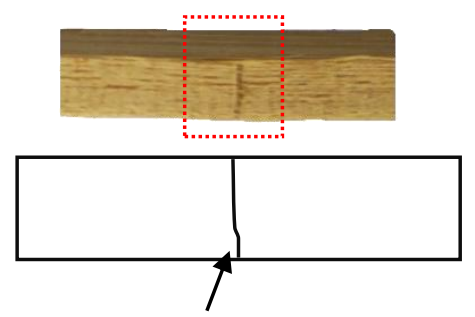

Failure mode

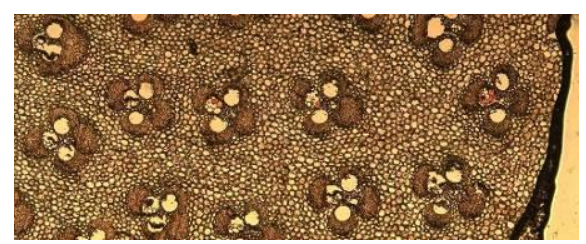

(b)
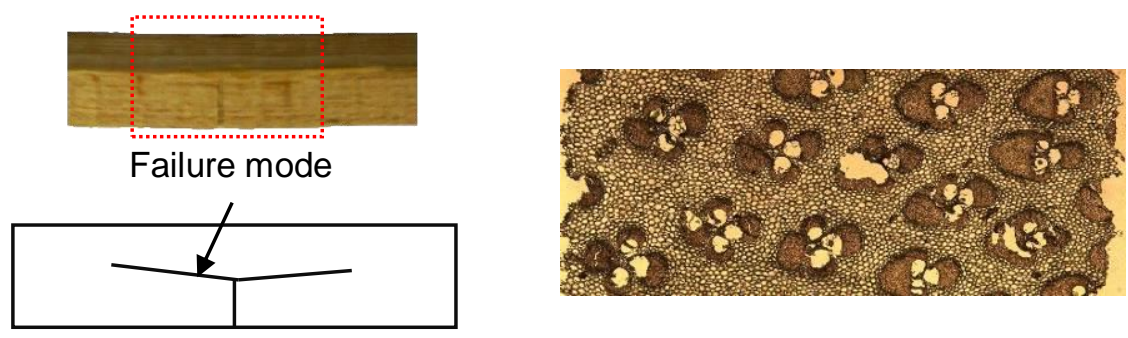

(c)
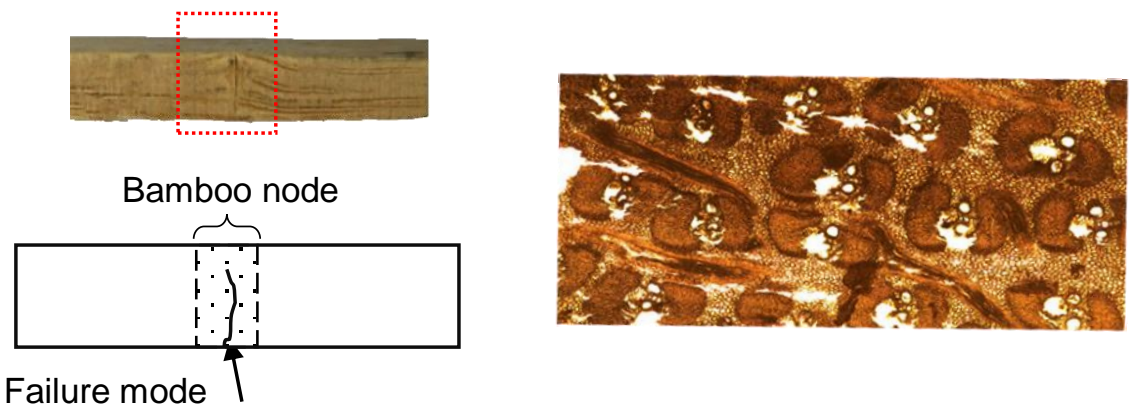

Fig. 6. Brash tension: (a) internode group and (c) node group; and simple tension: (b) internode group 
To the internode group, there was no significant association between the failure modes and the proportion of vascular bundle according to the variance analysis. Thus, the tissue distribution was a key factor in determining the propagated mode of cracking. The cohesion strength of parenchyma was weaker than that of the vascular bundle. Therefore, the breakdown point was located in the parenchyma, then it propagated through the nearest parenchyma in the opposite direction of pressure. If there was an adequate amount of vascular bundles at a certain height along the way, the failure mode of simple tension would occur under the action of shearing.

\section{Tensile Strength}

There was only an outlier in the samples for the node group. The data analysis except for the outlier is shown in Table 8. There were significant differences in tension strength between the node and internode specimens. Meanwhile, the tension strength of the internode group could be up to $39.0 \%$ higher than that of the node group (Shao et al. 2010).

The relationship between tension strength and tissues proportion for internode and node specimens is given in Fig. 7 and Table 9. There were 23 and 18 available slicing data for internode group and node group, respectively. A high tissues proportion corresponded to a high tension strength as a whole, and there was significant correlation between the two items. However, the tension strength in the node group had relatively higher dispersion from $26 \%$ to $40 \%$. The reason for that was the same as above described for the bending strength.

Table 8. Data Analysis of Tension Strength between Internode and Node Specimens

\begin{tabular}{|c|c|c|c|c|c|c|c|}
\hline \multirow{3}{*}{ Summary } & Group & $n$ & \multicolumn{2}{|c|}{ Mean (MPa) } & $\begin{array}{l}\text { Max. } \\
\text { (MPa) }\end{array}$ & Min. (MPa) & SD \\
\hline & Internode & 26 & \multicolumn{2}{|c|}{136.93} & 180.54 & 96.10 & 22.57 \\
\hline & Node & 28 & \multicolumn{2}{|c|}{98.52} & 136.33 & 62.48 & 20.32 \\
\hline \multirow{4}{*}{$\begin{array}{l}\text { Variance } \\
\text { Analysis }\end{array}$} & $\begin{array}{c}\text { Sources of } \\
\text { Variation }\end{array}$ & SS & $d f$ & MS & $F$ & P-Value & Significance \\
\hline & Between & 19894.24 & 1 & 19894.24 & 43.31289 & $2.3 E-8$ & Significant \\
\hline & Within & 23884.36 & 52 & 459.3146 & & & \\
\hline & Sum & 43778.6 & 53 & & & & \\
\hline
\end{tabular}

SS: stdev square; df: degree of freedom; MS: mean square; SD: standard deviation 


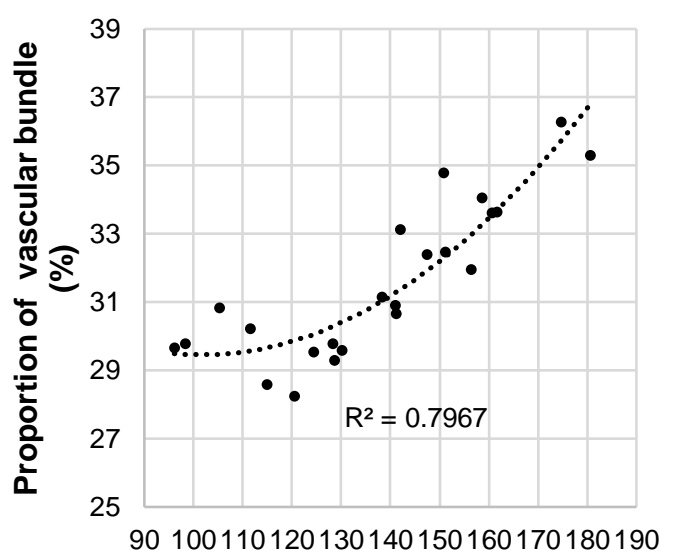

(a) Tension strength (MPa)

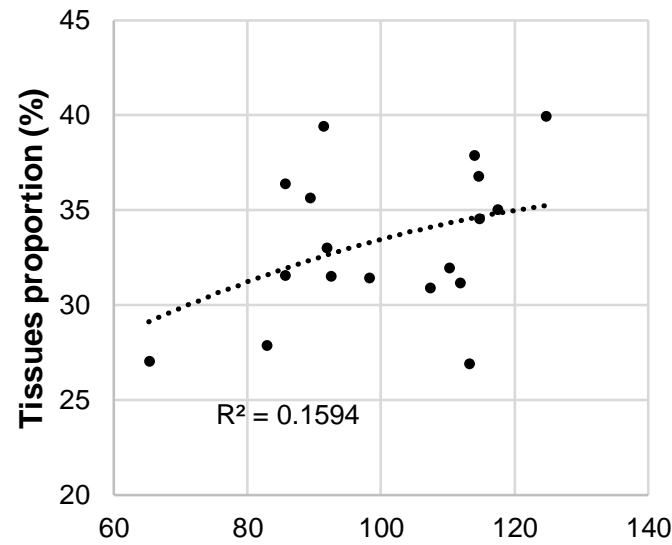

(b) Tension strength (MPa)

Fig. 7. Relationship between tension strength and tissues proportion: (a) internode and (b) node

Table 9. Variance Analysis of Tension Strength and Tissues Proportion

\begin{tabular}{|c|c|c|c|c|c|c|c|}
\hline \multicolumn{2}{|c|}{ Sources of Variation } & SS & df & MS & F & P-value & Significance \\
\hline \multirow{3}{*}{ Internode } & Between & 128910 & 1 & 128910 & 475.256 & $3.3 \mathrm{E}-25$ & Significant \\
\cline { 2 - 9 } & Within & 11934.7 & 44 & 271.243 & & & \\
\cline { 2 - 9 } & Sum & 140845 & 45 & & & & \\
\hline \multirow{3}{*}{ Node } & Between & 40710.79 & 1 & 40710.79 & 308.3456 & $1.27 \mathrm{E}-18$ & Significant \\
\cline { 2 - 9 } & Within & 4489.012 & 34 & 132.0298 & & & \\
\cline { 2 - 9 } & Sum & 45199.8 & 35 & & & & \\
\hline
\end{tabular}

SS: stdev square; df: degree of freedom; MS: mean square

The failures for tension strength were in three modes, namely brittle tension, splintering tension, and combined tension and shear (Fig. 8). 


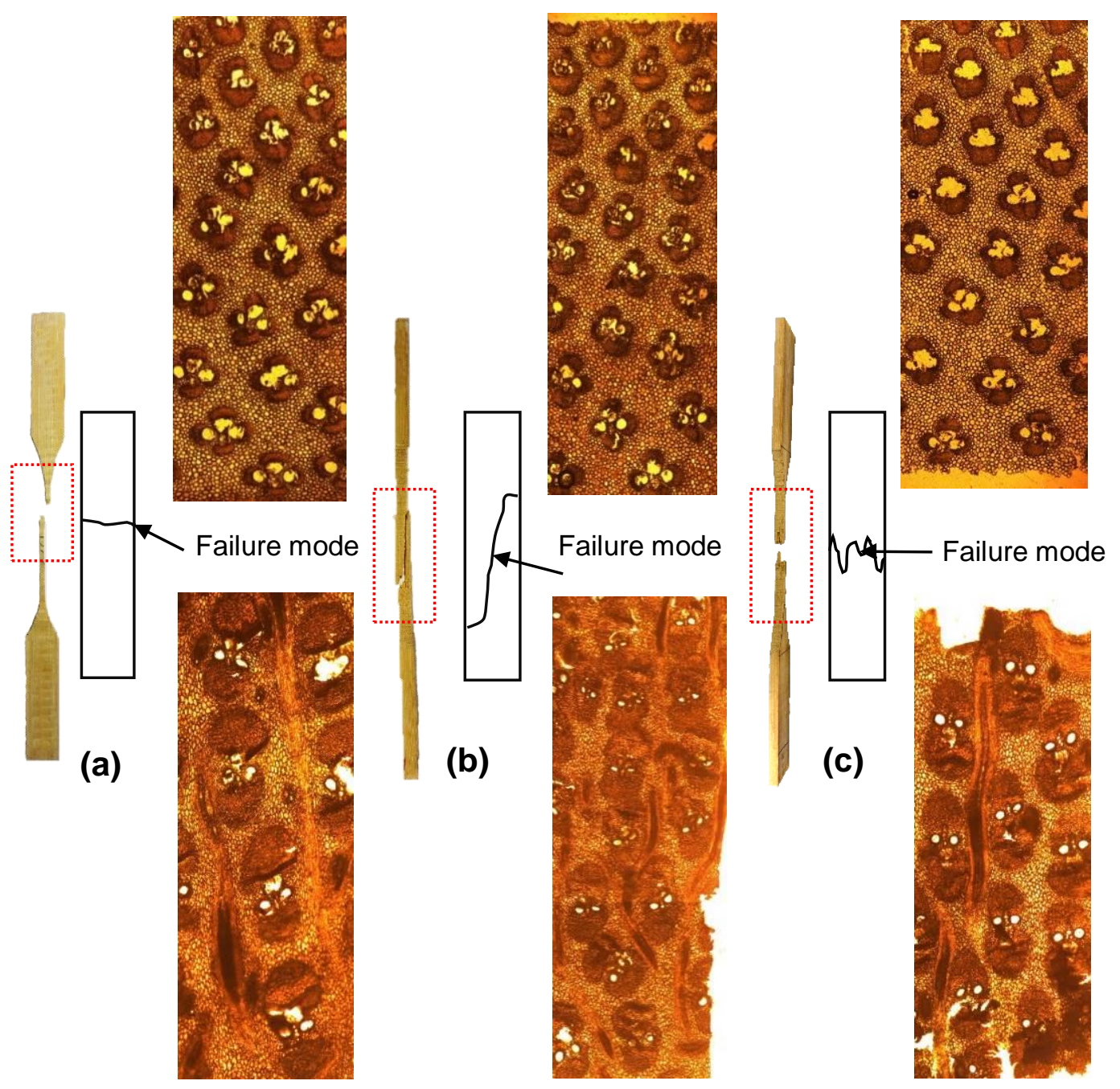

Fig. 8. (a) Brittle tension; (b) combined tension and shear; and (c) splintering tension; upper slices were part of internode group, and lower slices were part of node group

The failure modes of internode specimens mainly consisted in brittle tension $(39.1 \%)$ and combined tension and shear $(43.5 \%)$. Whereas, the node specimens failed mainly in the form of splintering tension (44.4\%) and combined tension and shear (44.4\%). Similarly, there was no significant relationship between tissues proportion and failure modes. The distribution characteristics of vascular bundle determined the failure modes of internode specimens, but the sheath-node was the key factor affecting the failure patterns of node specimens. It was because of the short length and random distribution of sheath-node, and the form of splintering tension would appear multiple times.

\section{CONCLUSIONS}

1. The compression strength was not influenced by the bamboo node. However, for failure modes of compression strength, the bamboo node reduced the probability of splitting by enhancing the transverse strength. 
2. The MOR, MOE, and tensile strength decreased with the presence of a bamboo node. Moreover, a bamboo node increased the dispersion of strength, and the likelihood of brash tension failure in the bending test and splintering tension failure in tension test. These were due to the following reasons: 1) the sheath-node was irregular with short length along the growth direction; 2) the vascular bundles in bamboo node were not fully differentiated; and 3) the sheath-node broke the fiber length in the growth direction and disturbed the arrangement of vascular bundles.

3. A high tissues proportion corresponded to a high compression strength, bending strength, and tension strength, but to a low elasticity modulus as a whole. However, there was no significant relationship between tissues proportion and failure modes in any tests. The tissues proportion distributed in the bamboo node was relatively discrete and a little higher than that in the internode. However, the high proportion in the node showed no significant effect on strength.

\section{ACKNOWLEDGMENTS}

This study was supported by the National Natural Science Foundation (NSFC) of China (Grant No. 31600455) and the "Spark Plan" Project of the Fujian Province of China (Grant No. 2018S0038).

\section{REFERENCES CITED}

Anwar, U. M. K., Zaidon, A., Hamdan, H., and Mohd Tamizi, M. (2005). "Physical and mechanical properties of Gigantochloa scortechinii bamboo splits and strips," Journal of Tropical Forest Science 17(1), 1-12. DOI:10.2307/23616523

Deng, J. C., Chen, F. M., Wang, G., and Zhang, W. F. (2016). "Variation of parallel-tograin compression and shearing properties in moso bamboo culm (Phyllostachys pubescens)," BioResources 11(1), 1784-1795. DOI: 10.15376/biores.11.1.1784-1795

Dixon, P. G., and Gibson, L. J. (2014). "The structure and mechanics of moso bamboo material," Journal of the Royal Society Interface 11(99), 1-12. DOI: 10.1098/rsif.2014.0321

Du, C. G., Jin, C. D., and Li, G. Y. (2013). "Study on gluing properties and surface wettability of radial bamboo strips," Advanced Materials Research 671-674, 17741778. DOI: 10.4028/www.scientific.net/AMR.671-674.1774

Food and Agriculture Organization of the United Nations (FAO) (2010). Global Forest Resources Assessment (Main report), Food and Agriculture Organization of the United Nations, Rome, Italy.

Fujii, Y., Azuma, J., and Okamura, K. (1996). "Changes in chemical composition within an internode of elongating bamboo," Holzforschung 50(6), 525-530. DOI: 10.1515/hfsg.1996.50.6.525

Gamuyao, R., Nagai, K., Ayano, M., Mori, Y., Minami, A., Kojima, M., Suzuku, T., Sakakibara, H., Ashikari, M., and Reuscher, S. (2017). "Hormone distribution and transcriptome profiles in bamboo shoot provide insights on bamboo stem emergence and growth," Plant \& Cell Physiology 58(4), 702-716. DOI: 10.1093/pcp/pcx023 
GB/T 15780 (1995). "Testing methods for physical and mechanical properties of bamboos," Standardization Administration of China, Beijing, China.

Guan, X., Yin, H. N., Liu, X. S., Wu, Q. R., and Gong, M. (2018). "Development of lightweight overlaid laminated bamboo lumber for structural uses," Construction and Building Materials 188(10), 722-728. DOI: 10.1016/j.conbuildmat.2018.08.107

Huang, P. X., Chang, W. S., Ansell, M. P., John Chew, Y. M., and Shea, A. (2015). "Density distribution profile for internodes and nodes of Phyllostachys edulis (Moso bamboo) by computer tomography scanning," Construction and Building Materials 93, 197-204. DOI: 10.1016/j.conbuildmat.2015.05.120

Jiang, J. L., Bachtlar, E. V., Lu, J. X., and Nlemz, P. (2017). "Moisture-dependent orthotropic elasticity and strength properties of Chinese fir wood," European Journal of Wood and Wood Products 75(6), 927-938. DOI: 10.1007/s00107-017-1166-y

Jiang, S. X., Zhang, Q. S., and Jiang, S. H. (2002). “On structure, production, and market of bamboo-based panels in China," Journal of Forestry Research 13(2), 151-156. DOI: $10.1007 / \mathrm{BF} 02857243$

Lo, T. Y., Cui, H. Z., Tang, P. W. C., and Leung, H. C. (2008). "Strength analysis of bamboo by microscopic investigation of bamboo fibre," Construction and Building Materials 22(7), 1532-1535. DOI: 10.1016/j.conbuildmat.2007.03.031

Lobovikov, M., Paudel, S., Piazza, M., Ren, H., and Wu, J. Q. (2007). World Bamboo Resources, Food and Agriculture Organization of the United Nations, Rome, Italy.

Mackenzie-Helnwein, P., Eberhardsteiner, J., and Mang, H. A. (2003). "A multi-surface plasticity model for clear wood and its application to the finite element analysis of structural details," Computational Mechanics 31(1-2), 204-218. DOI: 10.1007/s00466-003-0423-6

Mao, F. J., Zhou, G. M., Li, P. H., Du, H. Q., Xu, X. J., Shi, Y. J., Mo, L. F., Zhou, Y. F., and Tu, G. Q. (2017). "Optimizing selective cutting strategies for maximum carbon stocks and yield of moso bamboo forest using BIOME-BGC model," Journal of Environmental Management 191, 126-135. DOI: 10.1016/j.jenvman.2017.01.016

Penellum, M., Sharma, B., Shah, D. U., Foster, R. M., and Ramage, M. H. (2018).

"Relationship of structure and stiffness in laminated bamboo composites," Construction and Building Materials 165, 241-246. DOI:

10.1016/j.conbuildmat.2017.12.166

Peng, G. Y., Jiang, Z. H., Liu, X. E., Fei, B. H., Yang, S. M., Qin, D. C., Ren, H. Q., Yu, Y., and Xie, H. L. (2014). "Detection of complex vascular system in bamboo node by X-ray mu CT imaging technique," Holzforschung 68(2), 223-227. DOI: 10.1515/hf2013-0080

Ribeiro, R. A. S., Ribeiro, M. G. S., and Miranda, I. P. A. (2017). "Bending strength and nondestructive evaluation of structural bamboo," Construction and Building Materials 146(15), 38-42. DOI: 10.1016/j.conbuildmat.2017.04.074

Richard, M. J., and Harries, K. A. (2015). "On inherent bending in tension tests of bamboo,” Wood Science and Technology 49(1), 99-119. DOI: 10.1007/s00226-0140681-9

Shao, Z. P., Zhou, L., Liu, Y. M., Wu, Z. M., and Amaud, C. (2010). "Differences in structure and strength between internode and node sections of moso bamboo," Journal of Tropical Forest Science 22(2), 133-138. DOI: 10.2307/23616721

Taylor, D., Kinane, B., Sweeney, C., Sweetnam, D., O’Reilly, P., and Duan, K. (2015). "The biomechanics of bamboo: Investigating the role of the nodes," Wood Science and Technology 49(2), 345-357. DOI: 10.1007/s00226-014-0694-4 
Wang, Y. R., Su, M. L., Sun, H. Y., and Ren, H. Q. (2018). "Comparative studies on microstructures and chemical compositions of cell walls of two solid wood floorings," Journal of Wood Science 64(5), 501-508. DOI: 10.1007/s10086-0181743-7

$\mathrm{Xu}, \mathrm{F}$. (2010). "Structure, ultrastructure, and chemical composition," in Cereal Straw Resource for Sustainable Biomaterials and Biofuels, R. C. Sun (ed.), Elsevier B. V., London, England, pp. 9-47. DOI: 10.1016/B978-0-444-53234-3.00002-X

Zhang, X. X., Li, J. H., Yu, Z. X., Yu, Y., and Wang, H. K. (2017a). “Compressive failure mechanism and buckling analysis of the graded hierarchical bamboo structure," Journal of Material Science 52(12), 6999-7007. DOI: 10.1007/s10853017-0933-9

Zhang, Y., Du, J. J., Guo, X. Y., Yan, W. P., and Zhao, C. J. (2017b). “Threedimensional visualization of vascular bundles in stem nodes of maize," Fresenius Environmental Bulletin 26(5), 3395-3401.

Article submitted: September 19, 2019; Peer review completed: November 17, 2019; Revised version received: December 31, 2019; Accepted: January 1, 2020; Published: January 10, 2020.

DOI: $10.15376 /$ biores. 15.1.1430-1444 